\title{
THE APPLICATION OF THE DYNAMIC THEORY OF THE BURDEN OF PROOF IN CIVIL MATTER AFTER THE VALIDITY OF THE CODE OF CIVIL PROCEDURE OF 2015: AN ANALYSIS OF DECISIONS
}

\section{A APLICAÇÃO DA TEORIA DINÂMICA DO ÔNUS DA PROVA EM MATÉRIA CIVIL APÓS A PROMULGAÇÃO DO CÓDIGO DE PROCESSO CIVIL DE 2015: UMA ANÁLISE DE DECISÕES}

\section{GILBERTO FACHETTI SILVESTRE}

Professor do Departamento de Direito da Universidade Federal do Espírito Santo (UFES) e docente permanente do Programa de Pós-Graduação em Direito da UFES, no Mestrado em Direito Processual. Doutor em Direito Civil pela Pontifícia Universidade Católica de São Paulo (PUC/SP), Mestre em Direito Processual Civil pela Universidade Federal do Espírito Santo (UFES) e Bacharel em Direito pela Universidade Federal do Espírito Santo (UFES). Na UFES, exerceu as seguintes atividades administrativas: Chefe do Departamento de Direito, Coordenador do Colegiado do Curso de Direito, Subchefe do Departamento de Direito, Subcoordenador do Colegiado do Curso de Direito, Membro do Comitê Institucional de Iniciação Científica na área de Ciências Sociais Aplicadas. Atualmente, é Chefe da Seção de Procedimentos Disciplinares do Gabinete do Reitor e Subchefe do Departamento de Direito (biênio 2019-2021).

CAROLINA BIAZATTI BORGES Mestre em Direito Processual pela Universidade Federal do Espírito Santo (2019). Pós-Graduada em Direito Público e em Direito Processual Civil pela Damásio Educacional. Advogada. 


\title{
NAUANI SCHADES BENEVIDES
}

Mestre em Direito Processual pela Universidade Federal do Espírito Santo. Especialista em Direito Público e Processo Civil. Extensão universitária na Faculdade de Direito da Universidade do Porto.

\begin{abstract}
Objective: The objective of this paper is primarily to analyze how the dynamic distribution of the burden of proof was inserted in the Brazilian Civil Procedural law to rule specific situations of the civil jurisdiction. An analysis of the organization of the theme by the legislator of the Brazilian Civil Code of Procedure of 2015 in order to extend the probationary dynamic to all civil matters was made, as well as the roles of the burden of proof in the Brazilian law, as well as if the traditional rule of distribution of the burden of proof can coexist with the dynamic rule.
\end{abstract}

Methodology: The methodology used is based on bibliographic and legislation research, as well as on doctrine, jurisprudence and articles published in specialized journals.

Results: It was concluded that the express adoption of the theory of the dynamic distribution of the burden of proof by the legislator of the Brazilian Civil Code of Procedure of 2015 was salutary, because it offered the security needed to solve the problem of the production of the evidence in order to obtain an equitable decision. Although part of the legal literature and the vanguard jurisprudence of the Superior Court of Justice already defended its application in cases that it was impossible or very hard to one of the parties to prove the alleged fact in lato sensu civil actions, the establishment of the rule in the Code stimulates - or better, obligates - the judges to rethink about the way that the probationary charges are defined in the proceeding. The Brazilian Civl Code of Procedure of 2015 granted a new nature to the Brazilian civil procedure given that it encourages the cooperation between the plaintiff, the defendant and the judge and compels this one to act incisively to reach a fair and equality decision. For this reason, the dynamic distribution of the burden of proof is a product of the concern of the legislator with the most fragile part of the process, following the example of the consumerist legislation valid since the 1990's.

Contribution: The main contribution of this study relates to the discussion of the inversion of the burden of proof brought by the Brazilian Code of Procedure of 2015.

Keywords: Burden of proof; civil procedure; probation dynamics; theory of dynamic distribution of burden of proof; equitative decision. 


\section{RESUMO}

Objetivo: O objetivo deste artigo é analisar principalmente como a distribuição dinâmica do ônus da prova foi inserida na legislação processual brasileira para regular situações específicas da jurisdição civil. Foi feita uma análise da organização do tema pelo legislador do Código de Processo Civil brasileiro de 2015, a fim de estender a dinâmica probatória a todas as questões civis, bem como os papéis do ônus da prova na lei brasileira, bem como se a regra tradicional de distribuição do ônus da prova pode coexistir com a regra dinâmica.

Metodologia: A metodologia utilizada é baseada em pesquisas bibliográficas e legislativas, bem como em doutrina, jurisprudência e artigos publicados em periódicos especializados.

Resultados: Concluiu-se que a adoção expressa da teoria da distribuição dinâmica do ônus da prova pelo legislador do Código de Processo Civil brasileiro de 2015 foi salutar, pois ofereceu a segurança necessária para resolver o problema da produção de provas a fim de obter uma decisão equitativa. Embora parte da literatura jurídica e da jurisprudência de vanguarda do Superior Tribunal de Justiça já defendesse sua aplicação nos casos em que era impossível ou muito difícil para uma das partes provar o suposto fato em ações civis lato sensu, o estabelecimento da regra no Código estimula - ou melhor, obriga - os juízes a repensar sobre a maneira como a obrigação das provas são definidas no processo. O Código de Processo Civil de 2015 concedeu uma nova natureza ao processo civil brasileiro, uma vez que incentiva a cooperação entre o autor, o réu e o juiz e o obriga a agir incisivamente para alcançar uma decisão justa e equitativa. Por esse motivo, a distribuição dinâmica do ônus da prova é um produto da preocupação do legislador com a parte mais frágil do processo, seguindo o exemplo da legislação consumerista válida desde os anos 90.

Contribuições: A principal contribuição deste estudo refere-se à discussão da inversão do ônus da prova trazida pelo Código de Procedimento Brasileiro de 2015,

Palavras-chave: Ônus da prova, processo civil; dinâmica probatória; teoria da distribuição dinâmica do ônus da prova; decisão equitativa.

\section{INTRODUCTION}

Traditionally, the burden to prove in civil cases was assigned to the plaintiff, concerning the constitutive fact of plaintiff's right, and to the defendant, concerning the existence of deterrent, modifying or extinctive facts of the plaintiff's right. 
However, the legislator of the Code of Civil Procedure of 2015 (CCP/2015), aware of what the legal literature and the decisions of the Superior Court of Justice already defended, as well as the salutary experience of the Code of Consumer Defense of 1990, has established beyond that traditional theory the possibility of inversion of the proof's burden. It is the insertion of the theory of dynamic distribution of the burden of proof in the Brazilian Civil Procedure also called theory of the dynamic probationary charges.

According to the $\S 1$ of Article 373 of the CCP/2015, before the impossibility or excessive difficulty to fulfill the probationary burden or the greater ease to obtain the proof of the contrary fact, the judge must assign the burden of proof in a different way in a well-opined decision. This means in other terms that the burden of proof must be assigned to the party that has better conditions to produce the evidence. The adoption of this theory as a general rule of the lato sensu civil jurisdiction was established to solve a problem of possible lesion to the equity in the solution of concrete cases, which consists in the difficulty - or even the impossibility - to produce evidences, a situation called in the Civil Law by probatio diabolica and in the Common Law by devil's proof.

In this research, the objective, primarily, was to analyze how the dynamic distribution of the burden ofproof was inserted in the Brazilian Civil Procedural law to rule specific situations of the civil jurisdiction. An analysis of the organization of the theme by the legislator of CCP/2015 in order to extend the probationary dynamic to all civil matters was made, as well as the roles of the burden of proof in the Brazilian law. From these premises, the research analyzed how the traditional rule of distribution of the burden of proof can coexist with the dynamic rule.

At last, a few decisions from the Brazilian state appeal courts were chosen to be analyzed. The selection criteria was to study the most relevant decisions about the dynamic distribution of the burden of proof according to the matter they referred to in order to comprehend how the rule has been applied and if, prima facie, there were any benefits in its adoption by the legislator of CCP/2015. 
To reach such purposes, this research used as methodology the documental analysis of jurist's writings (literature or doctrine) and of some decisions selected from the State courts' websites.

In a context of diabolic proof (issue), the present research aimed to verify if the $\S 1$ of Article 373 of CCP/2015 has contributed to the solution of concrete cases with equity (issue) in these two first years of validity of the Code (2016-2017).

\section{BRIEF HISTORY OF THE DYNAMIC THEORY OF THE BURDEN OF PROOF IN THE BRAZILIAN LEGAL SYSTEM}

the theory of the dynamic distribution of the burden of proof, which was developed in a pioneer manner in the Argentinian law, it was inspired by issues of the forensic practice. The doctrine realized that in some cases the rules of distribution of probationary charges were too rigid and should be relativized in a way that the party that has better conditions to produce the evidence is the one who should do it (PEYRANO, 2015, p. 147-148).

In Brazil, the legislator of the Code of Civil Procedure of 1973 (CC/1973) established in Article 333 a static rule of distribution of the burden of proof through which the plaintiff was responsible to prove the constitutive facts of his right and the defendant should prove the deterrent, modifying or extinctive facts of the plaintiff's right. Therefore, there was not a legal opening that allowed the referred burden to be distributed in a fairer and more egalitarian way. The command was the following:

Art. 333. The burden of proof is entrusted: I - to the plaintiff, concerning the constitutive fact of his right; II - to the defendant, concerning the deterrent, modifying or extinctive facts of the plaintiff's right. Single paragraph. It is null the convention that distributes differently the burden of proof when it: I treats about non-disposable right of the party; II - makes excessively hard to one party the exercise of the right.

For a long time the inversion of the burden of proof was only authorized by law in specific cases, in which the Code of Consumer Defense - a law enacted in 
1990 - could be applied. Such law, valid until today, intends to protect the consumer, who is the most fragile party of the legal relation. One of the forms of protection, as established by the legislator, is the assignment of the burden of proof to the supplier, who has a better condition to disengage from it.

In Brazil, even before the advent of CCP/2015, the doctrine and the Superior Court of Justice already defended the necessity to assign the probationary burden accordingly to the particularities of the concrete case. Through this point of view, the static rule established in the Article 333 of CCP/1973 should be softened, even because the dismissal of the action based on the impossibility to prove facts violates the Article 5, item XXXV of the Federal Constitution of 1988 (FC/1988), which prescribes that the law must not exclude from the Judiciary appreciation a lesion or a threat to a right (principle of non-obviation of the jurisdiction).

Jurists already affirmed for this reason that the theory of the dynamic distribution of the burden of proof was the best alternative to balance the forces in the procedural relation, attending to the principle of isonomy, which is the reason why its application did not depend on an express legal forecast (CÂMARA, 2014, p. 439440). Moreover, the fundamental right to the adequate and effective court protection could be compromised by a fixed regulation of the burden of proof (MITIDIERO, 2012, p. 75).

The Superior Court of Justice, which is responsible to interpret the Brazilian federal law, pointing its meaning to unify former decisions, already declared that a decision that adopted the principle of the dynamic charge of the proof did not violate CCP/1973. Such is the understanding in the decision of the Recurso Especial (Special Appeal directed to the Superior Court of Justice) n. 69.309/SC of 1996:

CIVIL LIABILITY. DOCTOR. CLINIC. PROOF. 1. It does not violate the rule on proof the state court decision that, in addition to accept implicitly the principle of the dynamic charge of the proof, exams the probationary set and concludes by the defendant's guilt. 2 . Standing to be sued - the clinic initially searched by the patient. 3 . Add of scientific texts determined by the judge. regularity. 4. Liability of the clinic and of the doctor who carried the patient submitted to surgery, which resulted in the section of the medulla. 5 . Inexistence of violation of the law and divergence not demonstrated. Recurso Especial not acceptable for review. (SCJ, Recurso Especial 
69.309/SC, $4^{\text {th }}$ Panel, Reporting Justice Ruy Rosado de Aguiar, trial in June 18,1996). (Our translation).

In a posterior opportunity, in the trial of the appeal against the decision that resulted from the trial of the Recurso Especial (Special Appeal) no. 216,315/RS, in 2012, the Superior Court of Justice also declared that the theory of dynamic distribution of the probationary charges leads to a less rigid system and allows the judge, before the insufficiency of the general rule of the Article 333 of the CCP/1973, to modify the burden of proof assigning it to the party that has better conditions to produce it. The decision stated the following:

\begin{abstract}
CIVIL PROCEDURE. APPEAL ACCORDING TO SPECIFIC COURT REGULATIONS IN THE APPEAL IN RECURSO ESPECIAL. COMPULSORY LOAN ON ELECTRIC ENERGY. DISCLOSURE OF DOCUMENTS TO VERIFY THE AMOUNT PAID ON ELECTRICITY BILLS. LIABILITY OF THE COMPANY. 1. The judge may command that the company displays documents that are in its power in order to allow the correct calculation of the amount owed due to monetary correction of the value paid as compulsory loan. This providence is salutary and marches towards the principle of the effectiveness of the protection of the Court, considering that in these cases fifteen-year-old values are questioned normally amounts concerning payments made between 1977 and 1993, corresponding to the 72th, 82th and 143th General Extraordinary Assemblies of the company, that ratified respectively the $1^{\text {st }}, 2^{\text {nd }}$ and $3^{\text {rd }}$ conversions of credits in preferred stocks. It is not reasonable to demand from the taxpayer to keep all his monthly bills in order to calculate the owed amount. Indeed, the company must control the amounts paid and the amounts to be returned as compulsory loan on electricity, even because the company owns the credits in favor of the taxpayers, updates them, pays interests and later converts them into stocks. 2. There is no illegality in the decision that establishes that the company must present the mentioned documents because the theory of the dynamic distribution of the burden of proof leads to a less rigid system and allows the judge, before the insufficiency of the general rule of the Article 33 of the CCP/1973, to modify the burden of proof assigning it to the party that has better conditions to produce it. Therefore, there are no violations to the Articles 283, 333, I, and 396 of the CCP/1973. Appeal denied. (SCJ, Appeal on the Appeal on the Recurso Especial no. 216,315/RS, $2^{\text {nd }}$ Panel, Reporting Justice Mauro Campbell Marques, trial in October 23, 2012). (Our translation).
\end{abstract}

In 2009, the Superior Court of Justice stated that the inversion of the burden of proof was applicable to a case that discussed a fine due to environmental damage. In the trial of the Recurso Especial (Special Appeal) no. 1,060,753/SP, the company 
was responsible to prove that it did not pollute the environment or that the substance thrown was not potentially harmful. The content of the decision follows:

\begin{abstract}
CIVIL PROCEDURE. JURISDICTION TO TRIAL OF TAX EXECUTION OF A FINE DUE TO ENVIRONMENT DAMAGE. INEXISTENCE OF INTEREST OF THE FEDERAL GOVERNMENT. JURISDICTION OF THE STATE JUSTICE. COURT PROTECTION. OMISSION. NON-OCURRENCE. EXPERT EXAMINATION. ENVIRONMENT DAMAGE. RIGHT OF THE PURPORTED POLLUTANT. PRINCIPLE OF PRECAUTION. INVERSION OF THE BURDER OF PROOF. 1. The jurisdiction to the trial of tax execution due to environment damage filed by an independent governmental agency belongs to the state justice. 2. There is no offense to Article 535, II, of CCP/1973, if the court decides the essential questions of the case. 3 . The principle of precaution presupposes the inversion of the burden of proof, which means that the party that supposedly caused the environmental damage must prove that did not caused it or that that the substance thrown was not potentially harmful. 4. It is a subjective right of the supposed pollutant that an expert declares the ineffectiveness of the conduct. Data obtained in the internet are not sufficient to prove it. 5 . The expert examination is necessary every time that the proof of the fact depends on technical knowledge, which reveals applicable in the environmental ambit because of the complexity of the biome and the pollutant effectiveness of the products arising from the human resourcefulness. 6. Recurso Especial (Special Appeal) accepted to determine the remand to its origins with the annulment of all decisions from the dismissal of the expert evidence request. (SCJ, Recurso Especial no. 1,060,753/SP, $2^{\text {nd }}$ Panel, Reporting Justice Eliana Calmon, trial in December 1, 2009). (Our translation).
\end{abstract}

The decision of the Superior Court of Justice that can be considered the most emblematic about the theme was pronounced in 2013, a few years before the validity of CCP/2015. In the trial of the Recurso Especial (Special Appela) no. 1,286,704/SP, the Court recognized the possibility of a systematic interpretation of the Brazilian procedural legislation, in constitutional bases, in order to be applied the theory of the dynamic distribution of the burden of proof even without an express forecast in CCP/1973. The Court reached the following understanding:

CIVIL AND CIVIL PROCEDURE. REQUEST. INTERPRETATION. CRITERIA. PROOF. BURDEN. DISTRIBUTION. LITIGATION IN BAD FAITH. COLLECTION OF DEBT ALREADY PAID. INCIDENCE LIMITS. LEGAL ARTICLES ANALYZED: 17, 18, 125, I, 282, 286, 333, I AND II, 339, 355, 358, 359, 460 AND 512 OF CCP/1973 AND 1.531 OF THE CIVIL CODE OF 1916 (940 OF THE CIVIL CODE OF 2002). 1. Suit for damages filed in Feb. 16, 2001. Recurso Especial (Special Appeal) before the Justice since Oct. 21 $1^{\text {st }}, 2011.2$ Recurso Especial (Special Appeal) that discusses 
the limits of civil liability of the defendants by improper protest of promissory note [...]. 6. In the terms of the Article 333, II, of CCP/1973, the defendant must prove the existence of deterrent, modifying or extinctive facts of the plaintiff's right. 7 Although it has not been expressly contemplated in CCP/1973, a systematic interpretation of the Brazilian procedural legislation, in constitutional bases, gives a broad legitimacy to the application of the theory of the dynamic distribution of the burden of proof, according to which the burden is assigned to the party that has better conditions to produce the evidence, respected the phatic circumstances of each case. 8. The litigation in bad faith must be distinguished from the procedural strategy adopted by the party that opts for non-presenting certain documents that are contrary to his thesis, accepting the risks of this choice. The duty to collaborate with the justice must be confronted with the right of full defense, which includes the choice of the best tactic of resistance to the pretention. The behavior of the party must always be analyzed according to the peculiarities of each case. [...]. 11. Recurso Especial (Special Appeal) of the plaintiff denied. (SCJ, Recurso Especial (Special Appeal) no. 1,286,704/SP, $3^{\text {rd }}$ Panel, Reporting Justice Nancy Andrighi, trial in October 22, 2013).

The daily practice and the verification in concrete of situations in which the static distribution of the burden of proof was unfair and impeded the effectiveness of the proceeding opened way to the insertion, even if gradual, of the theory of the dynamic distribution of the burden of proof in Brazil in lato sensu civil matter.

In Civil Law countries the legal systems have as a paradigm the written law, even if the rule in it is not genuinely innovative, as in the present case. The legislator of CCP/2015 dedicated an article of the Code to the express adoption of the referred theory. According to the $\S 1$ of Article 373, in the cases established by the law or before the impossibility or excessive difficulty to fulfill the probationary burden or the greater ease to obtain the proof of the contrary fact, the judge must assign the burden of proof in a different way in a well-opined decision and must give the party the chance to get rid of the task.

However, the rule of static distribution was preserved by the legislator on the lead paragraph of the Article 373 of CCP/2015 and represents a rebuttable presumption (LOURENÇO; MENDES, 2017, p. 62). Therefore, it is possible that two different rules of distribution of the burden of proof might be applied to civil matters in general: 1) static, which is always legal (ope legis) and does not vary according to the cases' peculiarities, and 2) dynamic, which can be established by the judge (ope judicis) or by the parties. 


\section{THE BURDEN OF PROOF IN THE CODE OF CIVIL PROCEDURE OF 2015 AND ITS DOUBLE ROLE}

The procedural rules about the burden of proof are directed to the judge and to the parties. The doctrine affirms that these norms perform a double role: one objective and the other subjective.

According to the objective dimension, the rules about the burden of proof are directed to the judge, that must decide the case even if the facts are not completely uncontroversial or totally insufficient to reveal the truth. If the burden of proof is assigned to one of the parties but the evidence is not brought to the records, the judge when deciding can impute a disadvantage to that party. This is the reason why the doctrine affirms that, by the objective dimension, the burden of proof is a trial rule (WAMBIER et al, 2016, p. 722; DIDIER JR. et al, 2016, p. 111).

On the other hand, according to the subjective dimension, the rules about the burden of proof are directed to the parties. This means that the success or failure in a case depends on the adequate production of the evidence that the law (static rule) or the judge (dynamic rule) has previously determined. Each allegation that involves phatic matter is about a situation of life, ergo is the party responsible to prove its occurrence. Although the judge is obliged to decide even if the fact is not proven, his conviction is formed according to the elements brought to the records by the parties. A fair outcome depends on the adequate probation of the facts.

This double role allows the burden of proof to work as an important instrument of the principle of procedural cooperation, which was adopted by the legislator of CCP/2015 as a fundamental norm of the civil procedure. According to the Article 6, all subjects must cooperate to obtain a fair dismissal of the case with prejudice in a reasonable period. Even though the situation handed over to the Judiciary is conflicted, which means that parties have divergent interests, they must act loyal and in good faith providing elements to the judge in order to get an adequate solution (SOUZA, 2013, p. 67). 
The insertion of the theory of the dynamic distribution of the burden of proof by the legislator of $\mathrm{CCP} / 2015$ allowed a more effective perform of the subjective dimension, because it facilitates the evidence is brought to the records by the adequate party. Even though the parties are not financially equal, they are legally equal aseach of them must prove the fact according to their better conditions to produce the evidence.

Besides, it is important to highlight that the proof does not belong to the party, but to the proceeding, to the court.

The legislator of CCP/2015 opted for maintaining the static distribution of the burden of proof rule but allowed the dynamic distribution determined by the judge or by the parties.

\subsection{THE RULE OF STATIC DISTRIBUTION OF THE PROOF'S BURDEN}

The rule of static distribution of the burden of proof is established on the lead paragraph of the Article 373 of CCP/2015. It determines that the burden of proof is assigned to the plaintiff, concerning the constitutive fact of his right, and to the defendant, concerning the existence of deterrent, modifying or extinctive facts of the plaintiff's right. Such rule represents a legal hypothesis of the burden of proof distribution.

In other words, when there is no determination of the judge or convention of the parties disposing in a different manner, the burden of proof is assigned in those exact terms. For example, if the plaintiff claims the payment of a debt, he must prove the existence of the credit and that the due was not paid in the stipulated period. The defendant, however, carries the burden to prove that, for example, already paid (a fact that extinguishes the plaintiff's right). Therefore, the plaintiff proves through documentary or testimonial evidence the fact that originated the credit (the existence of a contract, for example) and the defendant must present the receipts that prove the payment and that the collection is improper. 
It is important to remind that the defendant has the right to simply deny the constitutive facts alleged by the plaintiff on his complaint. However, the chances to succeed are higher when a new fact (deterrent, modifying or extinctive of the plaintiff's right) is brought to court.

According to the static rule of distribution, the burden of proof is assigned exclusively to the party that alleges the fact. It is an ex lege criteria in which there is no participation of the judge, at least not a direct one.

The rule of static distribution was literally transported from CCP/1973 to $\mathrm{CCP} / 2015$ without any changes in the legal text. That Code reflected in its content the very feature of the state by the time it was enacted. The performance of the judge was one of the most affected aspects in the liberal state, because, as an state agent, the justice should act accordingly to the government profile. The less activist, participative and active was the judge, the more it would be fulfilling its role. He could only manifest himself when provoked in the form of the law, because only in this way the formal equality would be protected (RODRIGUES, 2015, p. 18).

During the time, some jurists and court decisions of the Superior Court of Justice, as mentioned, pointed to the insufficiency of the static rule to some concrete cases. In an alimony proceeding, for example, the defendant certainly had better conditions to prove his monthly income, and, in a winding up proceeding, the partners that remain in the company have better conditions to give information about the society than the excluded partner (MEDINA, 2016, p. 663). In cases like these, the parties would not be substantially equal before the court, because an impossible or very hard burden to get rid of would be assigned to one of them (devil's proof).

There are evidences considered "diabolic" by the jurists due to the impossibility or extreme difficulty to the party to produce them. The evidence can be diabolic to one or to both parties - as well as to the court, which sometimes is confined by a fragile probationary set, but even so must fulfill the principle of nonobviation of the jurisdiction (naha mihi factum, dabo tibi jus). In the first case, the burden of proof must be inverted, as will be explained on the next topic. In the second case, however, the judge must impute a disadvantage to the party that took 
the risk of the state of doubt, after all the judge must decide even if not completely convicted.

The rule of static distribution of the burden of proof is a legal imperative that does not demand that the probationary charges must be moved (or "redistributed") by the judge or by the parties. This rule is only applied to cases in which it is fair that the party produces the evidences concerning the facts that has alleged.

\subsection{THE RULE OF DYNAMIC DISTRIBUTION OF THE BURDEN OF PROOF}

The rule of dynamic distribution of the burden of proof is established on the $\S$ 1 of article 373 of $\mathrm{CCP} / 2015$. It determines that before the impossibility or excessive difficulty to fulfill the probationary burden in the terms of the lead paragraph (static rule) or the greater ease to obtain the proof of the contrary fact, the judge must assign the burden of proof in a different way in a well-opined decision and must give the party the chance to get rid of the task.

Therefore, if the proof of the fact is impossible or very hard to be produced by one of the parties, the judge must transfer the burden to the other, giving an opportunity in a reasonable period to the party to discharge from the burden. Similarly, the judge must act when the evidence is not impossible or very hard to be produced by one of the parties, but it is easier to one of them to obtain it. This means that the judge may assign to the plaintiff the burden to prove deterrent, modifying or extinctive facts of his right, or yet assign to the defendant the burden to prove constitutive facts of the plaintiff's right.

In a collection lawsuit, for example, the plaintiff might have a greater ease to prove that the defendant paid, bringing to the records a statement of his bank account that demonstrates the day and the time pointed by the other party as being the moment of the discharge from the debt. In an opposite way, in a lawsuit that discusses the legality of part of a purchase contract between two individuals the judge may determine that the defendant presents the contract if the plaintiff alleges that lost his copy, for example. 
The dynamic distribution does not depend on the kind of the alleged fact. It runs from the judge's perception about the concrete case. Every time the judge verifies that, without the inversion, the proceeding will not have a fair outcome, the dynamic rule must be applied.

$\S 2$ of Article 373 of CCP/2015 represents an obstacle to the judge. It determines that the judge must not apply the dynamic rule when the burden of proof assigns to the party an impossible or excessively hard task. Therefore, the judge must demonstrate in his grounds that if he inverts the burden he is not giving the party the burden to produce a diabolic evidence. This means that if the dynamic distribution provokes a reciprocal probatio diabolica between the parties, the one who alleged the fact of hard proofing will suffer the consequences.

The judge's performance must point to the impossibility of application of the static rule of distribution of the burden of proof (lead paragraph of the Article 373) in that specific case (ARENHART et al, 2016, p. 471). In order to avoid the probation diabolica, the judge must not apply the dynamic rule and impute in his final decision a disadvantage to the party that assumed the risk of the state of doubt around the fact, in cases that the impossibility to prove is configured to both parties.

In this sense, the dynamic distribution is an extraordinary and subsidiary measure when compared to the static rule and must only be applied when there are elements that show that the adoption of the general rule might lead the proceeding to a manifestly unfair outcome (PINHO, 2015, p. 158). The party that feels mistaken with the decision about the distribution of the burden of proof can use a specific appeal established by Article 1,015 of CCP/2015. This appeal challenges some interlocutory decisions pronounced in the proceeding. The most appropriate moments for the judge to distribute de burden of proof are the conclusive opening stage (Article 357, III, of CCP/2015) or the evidentiary stage, right before the final decision.

According to the will of the legislator, the judge must give the party an opportunity to get rid of the burden to prove. Furthermore, he must give the other party a period to opine about the produced evidence in respect of the adversary 
system. If the judge realizes that the dynamic rule must be applied after the evidentiary stage, he must delay the final decision and give the party the chance to produce the evidence and the other party the chance to manifest (LUCON, 2015, p. 579).

Moreover, it is possible that the parties make a convention before or during the proceeding (Article 373, § 4) and distribute the burdens between each other. $\S 3$ of Article 373 specifies that the parties can decide about the burden of proof as long as the convention does not treat about non-disposable right of the party or makes excessively hard to one party the exercise of the right. Such command is not entirely new. Just like the static rule of distribution of the burden of proof, the possibility of convention between the parties was established by CCP/1973 in the exact terms as transported to CCP/2015. During the validity of the previous Code, however, the parties almost never used the rule because the law did not stimulate the autonomy of their wills.

The convention about the burden of proof must not fall upon a nondisposable right of the party. According to the understanding of the Federal Supreme Court, a non-disposable right is the one coated by public interest. In the trial of the Extraordinary Appeal no. 248,869/SP, in 2003, the Court stated that the holder of a non-disposable right can never freely dispose of it, as there is an aspect of the common good in it (for example, the rights to life, to health, to paternity, etc). The legislator of CCP/2015 meant to avoid that these rights are objects of conventions about the burden of proof. Actually, there is no need for the legislator to expressly prohibit it, because the civil procedure law already forbids that the convention makes it excessively hard to one party the exercise of the right. This prohibition per se would be enough because it embraces both disposable and non-disposable rights. Therefore, there is no obstacle that the parties make a convention about a nondisposable right. For example, if a company commits to prove that the pollutant substances do not attack the environment (there is a non-disposable right to a balanced environment), the convention only facilitates the exercise of the right, even if it is non-disposable (DIDIER JR. et al, 2016, p. 123). 
If the convention makes the proofing of the fact easier, it is valid and effective, even if it treats about a non-disposable right. The validity of a procedural convention and its ability to produce effects in the proceeding must be verified by the judge, which must clarify in his decision what are the impacts of that juristic act on the case (MACÊDO; PEIXOTO, 2015, p. 474).

\section{ANALYSIS OF DECISIONS OF BRAZILIAN STATE APPEAL COURTS ABOUT THE DYNAMIC DISTRIBUTION OF THE BURDEN OF PROFF AFTER TWO YEARS OF VALIDITY OF CCP/2015 (2016-2017)}

The research of decisions did not intend, at first, to produce statistics to verify the existence of a jurisprudence about the matter in the ambit of the courts that were object of analysis.

The parameters of research were previously fixed and posteriorly applied in the section of decision research in the official websites of the courts, according to the following scheme:

\begin{tabular}{|c|c|}
\hline Object of the research & $\begin{array}{l}\text { Summaries and reports of court decisions } \\
\text { that applied directly the theory of the dynamic } \\
\text { distribution of the burden of proof }\end{array}$ \\
\hline Period & $\begin{array}{c}\text { Judiciary business days of } 2016 \text { and } 2017 \\
\text { (after the validity of CCP/2015) }\end{array}$ \\
\hline Date of research & From April 1 to April 8, 2018 \\
\hline Words searched & "Dynamic”; "burden"; "proof"; " 373 ". \\
\hline $\begin{array}{c}\text { Number of documents } \\
\text { found and selected to } \\
\text { analysis }\end{array}$ & c \\
\hline $\begin{array}{l}\text { Courts in which the results } \\
\text { were found }\end{array}$ & $\begin{array}{c}\text { Appeal Court of the State of São Paulo; } \\
\text { Appeal Court of the State of Mato Grosso do } \\
\text { Sul; Appeal Court of the State of Minas } \\
\text { Gerais; Appeal Court of the State of Rio } \\
\text { Grande do Sul. }\end{array}$ \\
\hline
\end{tabular}

In Brazil, in terms of Judiciary organization in civil matter (excluding the matter of appreciation of the Federal Justice, to which competes as a rule judging the cases in which there is interest of the federal government), there are judges that act 
in the first degree of jurisdiction, and above them there are state appeal courts (one in each state and one in the federal district and territories). Both the first-degree judge and the state courts protect the subjective right of the party and can review the whole matter discussed in the case in order to provide a fair outcome. Hierarchically, above these state courts there is the Superior Court of Justice, responsible for the interpretation of the federal law, and above it there is the Federal Supreme Court, responsible for the interpretation of the Constitution of the Republic. Both superior courts protect the objective right, which means that, in general, they are not concerned about the fairness of the case, but only with the integrity of the law itself.

CCP/2015 is valid since March 18, 2016. It has adopted expressly, as mentioned, the theory of the dynamic distribution of the burden of proof. There are not decisions of the Superior Court of Justice on the matter yet due to the short period of validity of the Code. However, the state appeal courts in their daily work of trial of appeals argued against decisions pronounced by the judges of first degree, have already judged some cases involving the theme. Therefore, some of these decisions were analyzed and explained below.

The Appeal Court of the State of São Paulo had the opportunity to judge two similar cases and gave the exact same solution to both of them. The summaries of the trials were the following:

INTERLOCUTORY APPEAL. IMPUGNED JUDICIAL ACT. CONCLUSIVE OPENING ORDER. DISTRIBUTION OF THE BURDEN OF PROOF. ASSIGNMENT OF THE BURDEN TO THE DEFENDANTS. Medical error. Act of the public health service. Burden of the state. Doctrine. Solution established by article $373, \S 1$, of CCP/2015. Dynamic distribution of the burden of proof. Doctrine. Adequacy. Appeal denied. (ACS/SP, Interlocutory Appeal no. 2101063-78.2016.8.26.0000, 9 $9^{\text {th }}$ Chamber of Public Law, Reporting Justice José Maria Câmara Junior, trial in July 16, 2016). (Our translation.)

INTERLOCUTORY APPEAL. SUIT FOR MORAL DAMAGES. Medical error. Appeal against the decision that assigned the proof's burden to the defendants. Dynamic distribution of the proof's burden according to Aarticle 373, § 1, of CCP/2015. Decision upheld. Appeal denied. (ACS/SP, Interlocutory Appeal no. 2068459-30.2017.8.26.0000, $7^{\text {th }}$ Chamber of Public Law, Reporting Justice Eduardo Gouvêa, trial in July 31, 2017). (Our translation.) 
In both cases, the court upheld the decision of the first-degree judge that determined that a municipal hospital should prove that a medical error did not happen or that the doctors' conduct did not cause the death of a person (in both examples, the sons of the appellants were supposedly killed by the hospital negligence). The Justice understood that the hospital had better conditions to prove that its medical team did not make any mistake. The appellants, on the other hand, did not have the required technical knowledge to demonstrate the existence of a medical error.

The Appeal Court of the State of Mato Grosso do Sul analyzed an execution in which the party alleged that made a loan to his nephew, the other party, and that the debt was not paid in the adjusted terms. The summary of the trial, freely translated, was the following:

INTERLOCUTORY APPEAL. MOTION TO STAY EXECUTION. BURDEN OF PROFF. Article 373, $\S 1$, of CCP/2015. Dynamic theory of the burden of proof. Application. Difficulty in obtaining documents by one of the parties. Possibility to modify the burden between the parties. Appeal accepted for review, but denied. (ACS/MS, Interlocutory Appeal n. 140684211.2017.8.12.0000, $2^{\text {nd }}$ Chamber of Civil Law, Reporting Justice Marcos José de Brito Rodrigues, trial in August 9, 2017). (Our translation.)

According to the decision, the first-degree judge inverted the burden to prove that the loan was paid and assigned it to the appellant (uncle). The court understood that the decision was right, because the appellant could bring to the records a bank statement, a payment receipt or a copy of his individual income tax. In this case, according to the static distribution, the burden to prove this fact (payment) would fall upon the nephew, but the court analyzed the circumstances of the case and decided otherwise in order to enable a fair final decision.

The Appeal Court of the State of Minas Gerais verified the possibility to apply the dynamic theory in a case that a company made a loan from a bank to foment its commercial activity. See the summary of the decision below, freely translated:

INTERLOCUTORY APPEAL. ACTION FOR CONTRATUAL REVIEW. REDISTRIBUTION. BURDEN'S PROOF. SUITABILITY. Before the 
presence of the requirements listed in the $\S 1$ of Article 373 of CCP/2015, it is viable and licit to redistribute the burden of proof. Appeal partially denied. (ACS/MG, Interlocutory Appeal n. 1.0024.15.169945-1/001 $10^{\text {th }}$ Chamber of Civil Law, Reporting Judge Álvares Cabral da Silva, trial in October 17, 2017). (Our translation.)

In this trial, the court stated that the bank should present the statements of the company account in order to demonstrate if the alleged payment was made. The bank, as a financial institution, had better conditions to produce the evidence, since it controls all clients' information and can detail their financial movements.

At last, the Appeal Court of the State of Rio Grande do Sul analyzed a case in which a woman suffered a car accident and had enormous hospital and medical expenses. She sent the receipts to the insurance company, but it denied the refund. Therefore, she filed a lawsuit requesting that the company presented the receipts of expenses that she previously brought to the administrative proceeding she had lost them. The summary of the trial was the following:

\begin{abstract}
INTERLOCUTORY APPEAL. CAR INSURANCE. INVERSION OF THE BURDEN OF PROOF. POSSIBILITY. 1. CCP/2015 kept the distribution of the burden of proof between the plaintiff (concerning the constitutive fact of his right) and the defendant (concerning the existence of deterrent, modifying or extinctive facts of the plaintiff's right). However, it allowed the application of the theory of the dynamic distribution of the burden of proof by the judge in the concrete case in the $\S 1$ of article 373. 2. Therefore, $\mathrm{CCP} / 2015$ brings expressly the dynamic distribution of the burden of proof and assigns it to the party that has better conditions to produce it before the phatic circumstances. 3 . In this case, I glimpse the possibility to invert the probationary charges in order that the defendant must present the documents required by the plaintiff. It is the insurance company that has the detailed control of the information and documents searched, bound to the claim of refund. 4. Appeal denied. (ACS/RS, Interlocutory Appeal n. 70069425502, $5^{\text {th }}$ Chamber of Civil Law, Reporting Justice Léo Romi Pilau Júnior, trial in August 31, 2016). (Our translation.)
\end{abstract}

The court understood in that opportunity that the request was fair and determined that the insurance company presented the documents, even because it had control of the administrative proceeding.

From the analysis of these decisions, it is remarkable that many conflicted situations of life, when submitted to the Judiciary, can only have a fair outcome if the 
dynamic distribution of the burden of proof is invoked in the case. The Brazilian state appeal courts have been applying the rule with prudence. There is a serious concern about the effective satisfaction of the rights, mostly when one of them is considered unable to produce the evidence. This justifies and stimulates the judges to invert the probationary charges, even because the duty to cooperate is also directed to him.

\section{CONCLUSION}

Considering that the Brazilian legal system is based on the Civil Law, the express adoption of the theory of the dynamic distribution of the burden of proof by the legislator of CCP/2015 was salutary, because it offered the security needed to solve the problem of the production of the evidence in order to obtain a equitable decision. Although part of the legal literature and the vanguard jurisprudence of the Superior Court of Justice already defended its application in cases that it was impossible or very hard to one of the parties to prove the alleged fact in lato sensu civil actions, the establishment of the rule in the Code stimulates - or better, obligates - the judges to rethink about the way that the probationary charges are defined in the proceeding.

CCP/2015 granted a new nature to the Brazilian civil procedure given that it encourages the cooperation between the plaintiff, the defendant and the judge and compels this one to act incisively to reach a fair and equality decision. For this reason, the dynamic distribution of the burden of proof is a product of the of the concern of the legislator with the most fragile part of the process, following the example of the consumerist legislation valid since the 1990's.

Even though the Code is new, it is already possible to perceive the efforts of the first-degree judges and state appeal courts to apply the rule, such as the efforts of the parties to ensure a balanced trial. The analyzed decisions demonstrate that there is a compromise of the procedural subjects with the search of a better way 
towards the fairness of the case and equity and the burden of proof is a fundamental instrument to reach this goal.

\section{REFERENCES}

ARENHART, Sérgio Cruz; MARINONI, Luiz Guilherme; MITIDIERO, Daniel. Novo Código de Processo Civil comentado. 2 ed. São Paulo: Revista dos Tribunais, 2016.

CÂMARA, Alexandre Freitas. Lições de Direito Processual Civil. vol. 1. 25 ed. São Paulo: Atlas, 2014.

DIDIER JR., Fredie et al. Curso de direito processual civil. v. 2. Salvador: Juspodivm, 2016.

LOURENÇO, Haroldo; MENDES, Aluisio Gonçalves de Castro. A teoria geral da prova no Código de Processo Civil de 2015. Revista de Processo, São Paulo, v. 263, p. 55-75, jan. 2017.

LUCON, Paulo Henrique dos Santos. Das provas. In: CABRAL, Antonio do Passo; CRAMER, Ronaldo (coord.). Comentários ao novo Código de Processo Civil. Rio de Janeiro: Forense, 2015.

MACÊDO, Lucas Buril de; PEIXOTO, Ravi de Medeiros. Negócio processual acerca da distribuição do ônus da prova. Revista de Processo, São Paulo, v. 241, p. 463487, mar. 2015.

MEDINA, Jose Miguel Garcia. Novo Código de Processo Civil comentado com remissões e notas comparativas ao CPC/1973. 4 ed. São Paulo: Revista dos Tribunais, 2016.

MITIDIERO, Daniel. Processo justo, colaboração e ônus da prova. Revista do Tribunal Superior do Trabalho, Brasília, v. 78, p. 67-77, jan./mar. 2012.

PEYRANO, Jorge W. De la igualdad probatoria formal a la real. Revista de Processo Comparado, São Paulo, p. 139-151, Jan./Jun. 2015.

PINHO, Humberto Dalla Bernardina de. Primeiras impressões sobre o sistema de distribuição do ônus da prova no CPC/2015. Revista dos Tribunais, São Paulo, v. 962. p. 153-170, Dec. 2015. 
RODRIGUES, Marcelo Abelha. Manual de execução civil. 5 ed. Rio de Janeiro: Forense, 2015.

SOUZA, Artur César de. O princípio da cooperação no projeto do novo Código de Processo Civil. Revista de Processo, São Paulo, v. 225, p. 65-80, Nov. 2013.

WAMBIER, Teresa Arruda Alvim et al. Primeiros comentários ao novo Código de Processo Civil: artigo por artigo. 2 ed. São Paulo: Revista dos Tribunais, 2016. 